\title{
Perspectives for school information systems
}

\author{
Graham Pegler \\ Department of School Education, NSW
}

\begin{abstract}
The development of information systems is often considered, overtly or covertly, in the context of large organisations. Schools, as organisations, need to confront many of the same problems in the development of appropriate information systems but also suffer from difficulties as a result of their size and their organisational nature. This paper attempts to provide an organisational perspective of the difficulties that schools face in developing an information system, the scope of such information systems and the directions in which schools have moved in implementing information systems.
\end{abstract}

\section{Schools as organisations}

Schools have specific organisational characteristics which distinguish them from most other organisations. These characteristics include a flatter hierarchy, a large proportion of semi-professional and autonomous staff members, and a range of roles undertaken by staff which are beyond those officially assigned, as well as having vague goals, and outputs which are difficult to directly relate to inputs (Brands, 1981, p. 820; Hedberg \& Harper, 1992). Such organisations are difficult to fit into a picture of organisations as rational, organised entities; they are more appropriately viewed as open systems (Williams, 1987, p. 146) in which loose coupling and spheres of influence develop and change in response to the external forces that impact upon the school.

Amongst those external forces are the larger authorities under which schools typically operate. In Australia, public schools operate under the auspices of a state government department which is usually divided into legions. The NSW Department of School Education is divided into 10 
regions, controlling over 2,000 public schools which have a combined enrolment of some three-quarter million students. In Britain the Department of Education and Science (DES) rules over Local Educational Authorities (LEA) which oversee schools (Bird, 1989, p. 19). In the USA the district school boards operate under the direction of state administration (Cheever, 1986). These authorities represent closely associated entities and hierarchical bureaucracies to which schools have to be accountable. They represent an important part of the school environment, placing demands upon them, both in terms of inputs and information output, shaping their structure and organisation. Other groups also have formal links to the school, through, for example, the academic reports of students, the proceedings of parent/school meetings and tertiary entrance scores. Schools are also subject to many other powerful external influences from the community, its citizens and businesses, as well as the demands of higher education authorities.

The introduction of a computerised school administration system could assist in making schools more efficient and effective in responding to the demands placed on the school internally by its staff and students and to the demands of the external entities with which it is associated. A computerised information system can also provide a buffer between the core teaching activity and participants of the school on the one hand, and the external entities on the other; one which will potentially improve the timeliness and accuracy of the communication between them. Improving the administrative management of the school can provide benefits in process management, the real task of the school, or at least of its academic staff (Brands, 1981, p. 820).

This distinction between administration and teaching is seen as important for another reason, as expressed in the Report to the Commonwealth Schools Commission by the National Advisory Committee on Computers in Schools (McShane, 1986, p. 26). They suggest that "if both use the same facilities then inevitably the teaching side is given second priority".

This brief view of the school as an organisation provides a perspective for the development of a school information system. An information systems development methodology which will assist in the creation of a stable model of the school's operations and/or enables the rapid development of systems to cope with changes in demands; that enables the accurate analysis of where the organisational boundaries are to be drawn, and the identification and understanding of both formal and informal flows of information intra-organisationally as well as between the organisation and its environment are important factors in selection of an appropriate methodology. The information system developed for such an environment should be one that is capable of withstanding change in the organisational environment or adapting to it. It cannot be based entirely on a "snap-shot" 
view of the school. The inadequacies of such a view could lead to the information system "tail" wagging the school management "dog". Although it is also reasonable to say that any information system will impose the assumptions made in modelling the system upon the organisation, better designed systems will provide the greatest flexibility (often by having fewer assumptions or constraints). Hedberg and Harper (1992) also point to the importance of the development of a "total information systems strategy" integrating the process management operations of the school and its administrative management for the full potential of a computerised school information system to be realised.

A consequence of the introduction of an information system is that it can make the organisation a more tightly coupled system. Tightly coupled systems can lead to disaster, organisationally speaking, if component failures prevent ongoing operations. In addition to the provision of backup and recovery facilities that can be provided by the system, decomposition of the conceptual model of the system into functional components can assist in identifying appropriate points at which components of the information system can be decoupled.

As each school is different, responding differently to the variations that exist in the school's environment, then each school, it may be argued, should have a unique information system. However the costs of such a development, in both monetary and human resource terms is too large to contemplate for individual schools, at least in the context of public schools in NSW. However, analysis reveals that there are useful universal stable features to school administration within an education system, which allow an information system to be developed for schools, provided that an appropriate perspective is taken and that methodologies and methods do exist to develop information systems in such an environment.

In addition, the powerful external influence of the governing body may require that the information system to be developed requires features that suit its requirements, especially as the governing body generally provides funding for the development of the system. These requirements may conflict with those of the schools, or at least they may not be required or anticipated by the school if it was to develop its own information system.

\section{The scope of computerised school administration}

School administrators, in the context described above, have, in their efforts to improve their lot, adopted different tasks for computerisation within schools. The range of tasks have included the development of databases for the recording of student enrolment details, family information, student absenteeism, marks and academic reports as well as staff and courses/classes details. However, these go only a step along the way of 
providing an information system of more wide-ranging use to a school. Other aspects given attention have been the computerisation of school library management and processes, school finances, stocktaking, school timetable development and management, school calendars and preparation of standard reports for higher authorities or external entities to whom they are accountable. These can provide increased efficiency in some aspects of school administration, however they generally represent simple data processing activities. Further, many of these applications were not integrated, they lacked coordination, and consequently the maintenance of the accuracy of the data often meant that the savings gained by computerisation of a process were lost.

Increased effectiveness can come about from these systems when they are used to form the basis for decision support systems. They can be used to assist in the evaluation of the effectiveness of school programs and funding, and so assist in making school management more effective.

For some, computerised administration can be extended to include instructional information systems designed to provide information and analysis to improve the way teachers teach and students learn. Stecher $(1986$, p165) would warn that the usefulness of such a management information system within a school depends not upon the amount of information it can provide but rather on "whether such information can help administrators help teachers to help students to learn". However, as alluded to earlier, the reactions of teachers to any intrusion into the classroom environment would need to be handled in such a manner as to maintain the professional responsibilities of the teacher. Responsibilities for instructional decisions lie with the professional teacher in the classroom; instructional information systems will not be successful by the exercise of administrative power.(King, 1987, p. 219) In most cases schools that are introducing computerised administration have concentrated development at the data processing level. This is in accord with the commonly accepted model for information systems within organisations which suggests that data processing applications used at an operational level form the basis for the development of management information systems used for planning and control, and, above this level, for the implementation of decision support systems used for analysis and strategic planning. (McFadden, 1991, p. 28)

Idstein (1987, p. 73) goes further. He sees the opportunity, through integrated school information systems, of revitalising the "learning webs" vision of Illich in Deschooling Society. Others also see opportunities, such as Cooley (1987, p. 89), of implementing McLuhan and Leonard's argument for redefining the nature of the school and the ways in which students participate. Such change certainly would demonstrate the capacity for strategic change that such systems could fulfil. 
An historical perspective to computerised school

\section{administration}

\section{The application of computers in schools}

Computers, specifically microcomputers, have been available within schools for some time now, some as early as the late 1970s. In that time a great deal of time, effort and money has been expended on the part of individuals and governments in the process of endeavouring to ensure that students become computer literate through interaction with computers and their applications. Indeed this has been a focus of government expenditure in NSW under the Department's Computers In Schools policy statement (1983). The perspective provided by this document for considering the application of computers in schools is useful here. Under this policy there are three main priorities in the use of computers within schools; the first two focus on the use of computers for teaching about computers and the use of computers as an aid to teaming. Many teachers have embraced the technology and are endeavouring to either employ it within their own area of expertise or are directly concerned with teaching about computers and associated technology. The demand in schools for courses about computing for students lead to the introduction of recognised "Computing Studies" courses for both senior and junior students in NSW, which rationalised and standardised the proliferation of school developed courses.

Lowest on the list of priorities is the use of computers for administration within schools. Many teachers have become aware of the value of computers for administration of their professional affairs and duties, not only at a personal class level, but also at a faculty level and whole-school level. As a result many dedicated and enthusiastic teachers have spent a great deal of time in developing systems which suit their personal circumstances or the particular circumstances of the school in which they teach. However, the low priority and stretched school funds meant it did not receive much assistance in the early years. In many smaller schools, it received no funding at all, as the more pressing needs of students were catered for.

There is no intention, in this view, for the integration of the learning environment and the administrative tasks that are potentially available.

\section{Early approaches to computerised school administration}

Much of the early progress in introducing computerised administration in schools was unfortunately on an ad-hoc basis, characterised by the acquisition of virtually any hardware that was available, with a reliance on the efforts of one or two keen members of the staff and different schools taking on different approaches as to what to computerise (Ardill, 1988, p. 
15). The directions undertaken on the limited budgets that schools had at their disposal for computerising school administration can be categorised into four available paths, although to varying degrees they are not mutually exclusive.

The first was to rely on the use of commercial general purpose programs; that is word processors, list managers (not true database programs ie. capable of establishing and maintaining links between files in a database), and spreadsheets to aid in the task of school administration. They were used to produce letters, academic reports, maintain information on students, class lists, rolls, marks, stock, predict staffing levels, assist budgeting etc. However, they were not ideal - the information was available at only one computer; or with multiple copies, the same data had to be maintained on different machines, and this of course led to problems in management of the integrity of the data and duplication of effort. Further, the software was not sophisticated; being incapable of providing online data entry validation through lookup tables, or of reporting based on the data in more than one file or the software had limitations in terms of capacity eg. the number of records that could be maintained. The computers themselves had limitations in terms of memory and processing power that reduced the effectiveness with which computer administration could be performed.

The second path was the development of software specific to the needs of schools by the computer buff(s) of the school. Here, however, the data was not easily transferable from one application to another (or to different machines), the applications written by different individuals were written in different languages on different hardware platforms and suited the circumstances of that school, had different methods of storing data, different meanings to the data they stored, provided different solutions to the same problem or were tied to the expertise of the individual - once the computer buff moved on, the application was not maintained and fell into disuse (Ardill, 1988, p. 16). In NSW, a number of administration programs were taken up by the Department and made available to schools throughout the state (SACP, 1989, p. 3). These included markbook programs, software for timetable management and for parent-teacher interviews etc. These were offered by the Department in 1985 (SACP, 1989, p.1) as "entry-level" software for school administration. The software developed by some others became available commercially; programs for markbooks, test generation and timetable management appeared. Others shared the templates or database structures they utilised with colleagues.

The third approach was to wait and see and not to engage in computerisation of administration at all and thereby take advantage of the lessons learnt by others. However, as Sungalia (1984) points out, this too was not satisfactory. Apart from missing out on the opportunity to develop skills in the school staff, it also reflected poorly on the school itself 
as a forward looking entity, as one that shows by example to students the way forward. The problem also existed for these schools as to when to jump in, especially as this was a new and rapidly changing technology, one which presented considerable risk particularly to those that were unfamiliar with it.

A much less common approach in Australia, which appears to have been more popular in the United States, was the use of mainframe computers available through time-sharing facilities from a computer services company or the education authority to conduct batch processing operations or special tasks. Such a system operated for one school described by Cannings and Polin (1987, p. 49) utilising the database program at the district office. The introduction of such systems was necessarily supported by the allocation of expertise at the mainframe site. The costs of access, and of personnel, and the inflexibility of the systems provided appear to have mitigated greatly against their increased use (Cheever, 1986, p. 2,9). In Britain trials were conducted utilising the IBM mainframe of a local authority. Again, the costs were too great for the local authority to consider connection of all schools (Ardill, 1988, p. 15).

It would appear that there was little attempt at a coordinated approach to attacking the problem of computerised administration of schools. The skills of the teachers and administrators involved was not in systems development. However, the applications developed were valuable. They provided useful tools and an opportunity for school administrators to become involved and appreciate the problems of systems development. They could also provide a useful basis for analysis of user requirements for any new developments.

The analysis of requirements for, and the production of, integrated systems for school administration were, while being pursued by some, apparently delayed by the lack of available funds, the limitations of hardware and software and a lack of know-how, coordination of effort and knowledge of the benefits and possibilities of computerisation. So, while computerisation was generally seen and felt to be useful, school administration still awaited a "coming of age".

\section{Commercially available school administration packages}

Gradually, commercial software began to appear that were specifically orientated to the administration of schools and suitable for use on microcomputers. Programmable databases for microcomputers also came within the reach of schools, and some began to take advantage of them. Sophisticated integrated packages such as Open Access were also utilised, if only to establish how useful they were for school administration on a trial basis. (SACP, 1989, p8) 
The improvements in technology (smaller size, greater memory, higher speeds, larger capacity secondary storage), lower costs, and the introduction of programs specifically aimed at school administration, enabled another avenue to be opened up. The evaluation, or development, of a total solution by the educational authority on the behalf of the schools in its control. Such an approach promised better leverage of the market and better analysis of requirements for an integrated approach.

In NSW, in an evaluation of school administration software was undertaken by the Department of Education, including MacSchool for the Apple Macintosh, and, running on MS-DOS compatible computers, SAM, CBASS, MAZE, and SCHOOL CARE. Each of these was investigated and evaluated by schools or officers of the NSW Education system; some underwent trials in schools. SIMS is a another package that has received attention from the educational authorities in Britain (Bird, 1989, p. 21).

Many other packages probably exist, and generally provide support, through a DBMS, for the above data processing activities. Some claim to provide support for decision-making activities, particularly in relation to timetable development. While these packages presumably represent a considerable investment in terms of the time spent in analysis and design of school information systems they vary in at least two fundamental respects; the relationships that exist between various files and data elements is different in different packages and secondly the amount of control users have over the access and control of the information they store. The first represents differences in the definitions of objects or entities that exist in a school environment. These differences relate to the specific school system in which the information system is to be applied, the implications of which mean that an information system that is developed for one school system may not have the correct relationships between important entities for use in another school system. The second is of concern in terms of privacy and integrity of data items that the system stores. Apart from the myriad of differences that exist in terms of user interfaces, range of services provided by the package and supplier, flexibility of design, ease of data retrieval, methods of storing and recovering data etc., these fundamental differences are crucial to the selection of a system by a school which suits their needs and does not cause the information system "tail" to wag the school management "dog". Such differences may only become important at a later date in the operation of the system to those who aren't aware of the implications. Selection then, at a school by school level, without professional assistance, may be made on the basis of a lack of knowledge of what is really being purchased. It is no trivial matter. 


\section{Conclusion}

The work of Nolan and Gibson as described by McNurlin and Sprague (1989, p. 97), and of McFarlan and McKenney in the same book, on the stages of growth of the EDP function in an organisation appear to be reflected well in the case of schools. The initial period of early success and investment in the application of the technology, followed by proliferation and experimentation are clearly part of the experiences of school administrators.

School information systems offer the potential to change the way schools Work, however that potential will not be realised by utilising the piecemeal, one-off approaches of the past. Effective and efficient school administration systems require an appreciation of the nature of the data and its relationships, and the need for data integrity On the basis of this understanding and the needs of the school and its staff, solutions to the school administration problem can be sought which conform to what is required and do not dictate what will be.

In the NSW school system the third stage of control and integration has been undertaken through the development of OASIS (Office Administration and School Information System). The management of this stage was clearly undertaken, not by the school, but by the Department. The absence of expertise at a school level, the diversity of schools and the solutions developed by them, required that action be taken at a higher level in the system in order to control the proliferation of solutions.

The value of recognising the stage at which the organisation currently exists is that the organisation can then focus on appropriate strategies to assist in the movement through the current stage to the next. The development of OASIS provides a case in point and the processes that led to its development will be considered in another paper.

Greater challenges remain. The challenge of successfully integrating both the administrative information system and educational activities of the school requires not only a strategic model of how such a system could work, it would also need to account of the multitude of different approaches professional staff would take to its imposition without losing (or feeling a loss of) their professionalism in utilising it.

\section{References}

Ardill, T., Nye, C. \& Rayment, A. (1988). School Administration on the IBMPC. In Barnetson, P. (Ed), IBM Personal Computing in Schools. London: Kogan Page, pp 14-29.

Bird, P. (1989). Countdown to Local Admin. Educational Computing, 10,(1), 1921. 
Brands, J. A. (1982). Adoption and Implementation of (Micro)computers in School Organisations in Computers in Education. In Lewis, B. \& Tagg, D. (Eds), Proceedings of the IFIP, Panel Discussions, Third World Conference on Computers in Education, North-Holland, p820.

Cannings, T. \& Polin, L. (1987). The Computer as an Administrative Tool: A Survey of 30 High Schools. In Bank, A. \& Williams, R. C. (Eds.), Information Systems and School Improvement: Inventing The Future. New York: Teachers College Press, pp 39-56.

Cheever, D. S., Coburn, P., Digiammarino, F., Kelman, P., Lewd, B. T., Naiman, A., Sayer, G. A., Temkin, K. \& Zimmerman, L. K. (1986). School Administrator's Guide to Computers in Education, New York: AddisonWesley.

Cooley, W. (1987). Developing an Elementary School Information System: The Computer Assisted Professional. In Bank, A. \& Williams, R.C., Eds. Information Systems and School Improvement: Inventing The Future. New York Teachers College Press, pp 86-96.

Hedberg, J. G. \& Harper, B. (1992). Information Systems Strategy in the Small Educational Organisation, In Windley, G. \& MacGregor, R, Eds., 3rd Australian Conference on Information Systems, ACS, University of Wollongong, October 5-8.

Idstein, P. (1987). We'll Create the Future But Keep It Secret. In Bank, A. \& Williams, R. C. (Eds.), Information Systems and School Improvement: Inventing The Future. New York: Teachers College Press, pp 57-75.

King, J. L. (1987). A Practical Assessment of Computerisation in Schools In Bank, A. \& Williams, R.C., Eds. Information Systems and School Improvement: Inventing The Future. New York: Teachers College Press, pp 119-135.

McFadden, F. \& Hoffer, A. T. (1991). Database Management. New York: Benjamin/Cummings.

McNurlin, B. C. \& Sprague, R. H. (1989). Information Systems Management in Practice. New York: Prentice-Hall.

McShane, R., Fitzgerald, D., Halliwell, G., Penter, K., Richards, H., Smulders, M. \& Woodrow, D. (1986). Australian School Computer Systems - Educational User Requirements: Appendix 1: Administrative Applications of Computers in Schools. National Advisory Committee on Computers in Schools: Report to the Commonwealth Schools Commission, pp 25-27.

NSW Department of Education. (1983). Computers in Schools: A General Policy Statement, August.

School Administration Computerisation Project (SACP) (1989). A History of Development; Information File, (unpublished), 15/5/89

Stecher, B. (1987). Superintendents don't type - advice for those setting up IIS training programs for administrators. In Bank, A. \& Williams, R. C. (Eds.), Information Systems and School Improvement: Inventing The Future. New York: Teachers College Press, pp 159-166. 
Sungalia, H. (1984). Managing school data on computer. Practising Administrator, 6(2), pp 6, 7, 30 .

Williams, R. C. \& Bank, A. (1987). Realities and Scenarios: Instructional Information Systems in the Classrooms of the Future. In Bank, A. \& Williams, R. C. (Eds.), Information Systems and School Improvement: Inventing The Future. New York: Teachers College Press, pp 145-151.

Author: Graham Pegler is currently studying for a Honours Masters Degree in Commerce specialising in Management Information Systems where he is undertaking research into the application of information systems modelling and methodologies to specification of school information systems. He is currently Senior Education Officer, NSW Dept of School Education, MIS Directorate, School Systems Project. He was previously a high school science and computing studies teacher responsible for coordination of the school's efforts in provision and use of computer technology including the implementation of OASIS (the Department of School Education's school administration system).

Please cite as: Pegler, G. (1992). Perspectives for school information systems. Australian Journal of Educational Technology, 8(2), 161-171. http: / / www.ascilite.org.au/ajet/ajet8/ pegler.html 